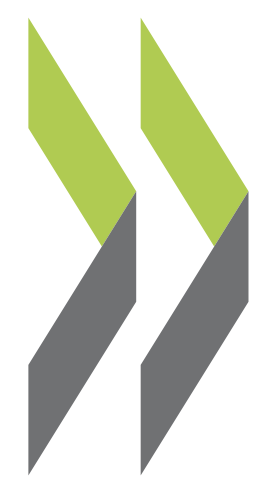

OECD Economics Department Working Papers No. 1458

How to improve Norway's Transport-Infrastructure Investment

\section{Philip Hemmings,}

Jagoda Egeland,

Juan Garin 


\section{Unclassified}

ECO/WKP(2018)5

Organisation de Coopération et de Développement Économiques

Organisation for Economic Co-operation and Development

19-Feb-2018

ECONOMICS DEPARTMENT

English - Or. English

\section{HOW TO IMPROVE NORWAY'S TRANSPORT-INFRASTRUCTURE INVESTMENT}

ECONOMICS DEPARTMENT WORKING PAPERS No. 1458

By Philip Hemmings, Jagoda Egeland and Juan Garin

OECD Working Papers should not be reported as representing the official views of the OECD or of its member countries. The opinions expressed and arguments employed are those of the author(s).

Authorised for publication by Alvaro Pereira, Acting Chief Economist, Economics Department.

All Economics Department Working Papers are available at www.oecd.org/eco/workingpapers

JT03426957

This document, as well as any data and map included herein, are without prejudice to the status of or sovereignty over any territory, to the delimitation of international frontiers and boundaries and to the name of any territory, city or area. 
OECD Working Papers should not be reported as representing the official views of the OECD or of its member countries. The opinions expressed and arguments employed are those of the author(s).

Working Papers describe preliminary results or research in progress by the author(s) and are published to stimulate discussion on a broad range of issues on which the OECD works.

Comments on Working Papers are welcomed, and may be sent to OECD Economics Department, 2 rue André Pascal, 75775 Paris Cedex 16, France, or by e-mail to eco.contact@oecd.org.

All Economics Department Working Papers are available at www.oecd.org/eco/workingpapers.

This document and any map included herein are without prejudice to the status of or sovereignty over any territory, to the delimitation of international frontiers and boundaries and to the name of any territory, city or area.

The statistical data for Israel are supplied by and under the responsibility of the relevant Israeli authorities. The use of such data by the OECD is without prejudice to the status of the Golan Heights, East Jerusalem and Israeli settlements in the West Bank under the terms of international law.

Latvia was not an OECD Member at the time of preparation of this publication. Accordingly, Latvia does not appear in the list of OECD Members and is not included in the zone aggregates.

\section{(C) OECD (2018)}

You can copy, download or print OECD content for your own use, and you can include excerpts from OECD publications, databases and multimedia products in your own documents, presentations, blogs, websites and teaching materials, provided that suitable acknowledgment of OECD as source and copyright owner is given. All requests for commercial use and translation rights should be submitted to rights@oecd.org 


\section{ABSTRACT/RESUMÉ}

\section{How to improve Norway's transport-infrastructure investment}

Norway makes substantial public investment in transport and this has intensified in recent years. There is potentially large economic benefit from such investment, particularly as good transport infrastructure can help Norway's transition away from oil-related activities. However, realising these gains requires sound processes for selecting and delivering projects. This paper assesses the investment process from initial proposals through evaluation, discussion, selection, approval, implementation, and ex post evaluation. It finds that, although the policy process at each stage is clear, and the planning framework has central oversight, final choices of project are often sub-optimal. The paper identifies a need for stronger top-down influence in the planning process and more influence of economic-efficiency considerations in project selection. It also calls for efforts to broaden ex post assessment of transport investment projects and reduction in project delays.

This Working Paper relates to the 2017 OECD Economic Survey of Norway

(www.oecd.org/eco/surveys/economic-survey-norway.htm).

JEL classification JEL codes: R42

Keywords: transport investment, project selection, cost-benefit analysis, ex-post assessment

$* * * * * * * * * * * *$

\section{Comment la Norvège peut-elle améliorer ses investissements en infrastructures de transport ?}

Les investissements publics de la Norvège dans les transports sont importants et s'intensifient depuis quelques années. Ils pourraient produire des retombées économiques non négligeables, notamment parce que des infrastructures de transport de qualité peuvent aider la Norvège à réaliser sa transition vers une économie moins centrée sur les activités pétrolières. La concrétisation de ces retombées nécessite toutefois des processus judicieux de sélection et d'exécution des projets. Cette étude évalue l'ensemble du processus d'investissement suivi en Norvège, depuis la proposition initiale jusqu'à l'évaluation ex-post, en passant par l'évaluation, l'examen, la sélection et l'approbation. Les auteurs de l'étude concluent que même si le processus est clair à chacune des étapes et si le cadre de planification fait l'objet d'une supervision centrale, les choix de projet arrêtés en bout de ligne ne sont souvent pas optimaux. Les auteurs mettent en évidence la nécessité d'exercer une influence descendante plus forte dans le processus de planification et de faire une place plus importante aux considérations d'efficience économique dans la sélection des projets. Ils préconisent aussi d'élargir l'évaluation ex-post des projets d'investissement dans les transports et de réduire les retards dans l'exécution des projets.

Ce Document de travail se rapporte à l'Étude économique de l'OCDE de la Norvège, 2017

Classification I23, I28, L53, 031, O38

Mots clefs : investissement en transport, sélection de projet, analyse coûts-bénéfices, estimation ex-post 


\section{TABLE OF CONTENTS}

HOW TO IMPROVE NORWAY'S TRANSPORT-INFRASTRUCTURE INVESTMENT .......................6

Geography and socio-political priorities strongly influence Norway's transport investment.....................7

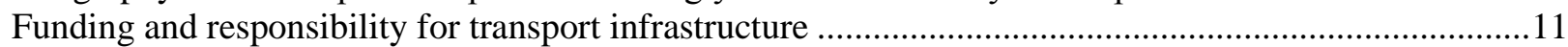

Recent reforms have included establishment of new road and rail companies ...................................12

Transport-infrastructure investment is driven by multi-annual National Transport Plans........................13

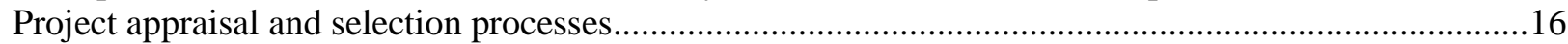

The two-stage quality assurance process for large projects ................................................................17

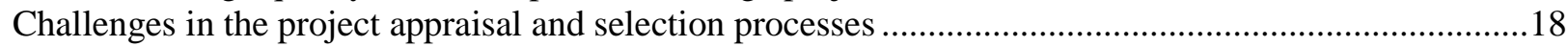

Economic efficiency considerations do not have enough influence.....................................................18

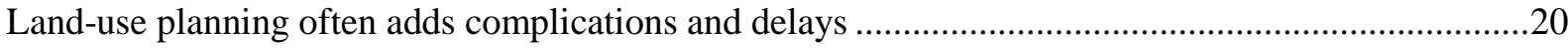

Measures already taken include steps for more evidence-based project selection .................................21

Further steps should include stronger top-down influence in the planning process...............................21

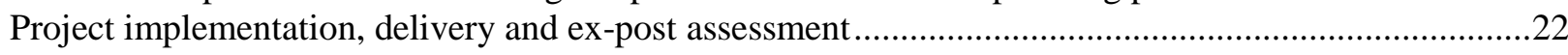

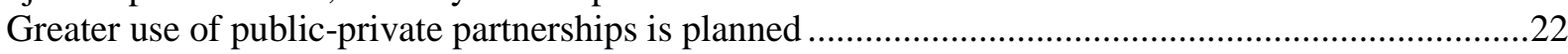

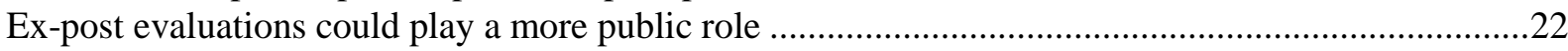

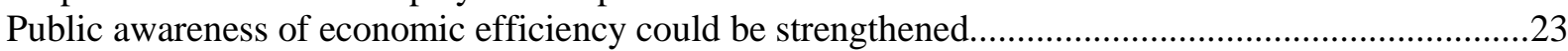

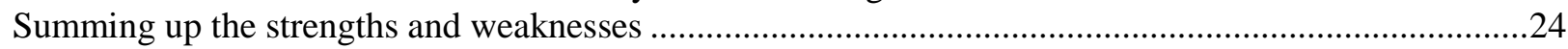

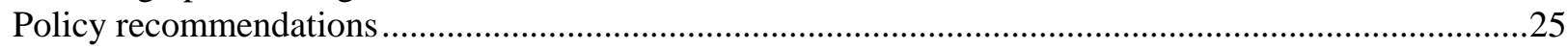

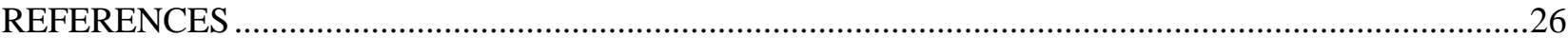

\section{Tables}

1 Population and transport-network densities in selected countries ....................................................

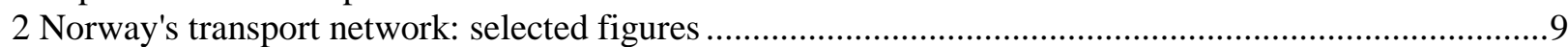

3 Benefit-cost summary for major road corridor projects initiated in the period 2014-2017 (NOK

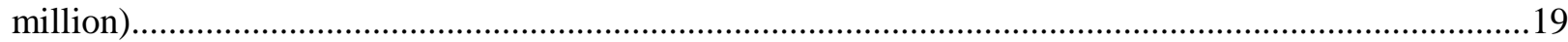

4 Strengths and weaknesses in transport infrastructure investment ......................................................24

\section{Figures}

1 Norway makes sizeable investment in transport infrastructure .......................................................

2 Low transport-network densities partly reflect low population density .............................................

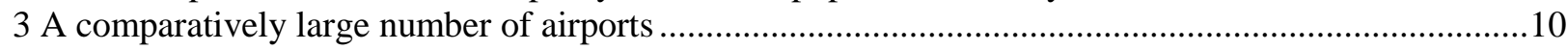

4 Mediocre scores in the World Economic Forum transport indicators ..................................................11

5 Norway's Quality Assurance regime for major public investment projects .......................................18

6 Investment efficiency of projects selected in Norway's National Transport Plan 2014-23...................20 
ECO/WKP(2018)5

\section{Boxes}

Box 1 The role of the Norwegian Public Roads Administration ...........................................................13

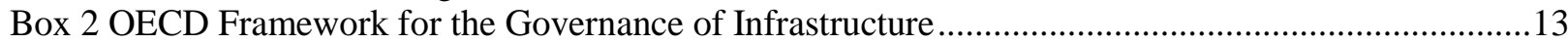

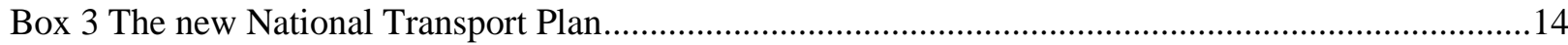

Box 4 Infrastructure planning and financing in the city of Oslo......................................................15

Box 5 Norway's "Circular R-109” guidelines for cost-benefit analysis ................................................16

Box 6 Recommendations on how to improve transport-infrastructure investment in Norway .................25 


\title{
HOW TO IMPROVE NORWAY'S TRANSPORT-INFRASTRUCTURE INVESTMENT
}

\author{
By Philip Hemmings, Jagoda Egeland and Juan Garin ${ }^{1}$
}

\begin{abstract}
Norway makes substantial public investment in transport and this has intensified in recent years. There is potentially large economic benefit from such investment, particularly as good transport infrastructure can help Norway's transition away from oil-related activities. However, realising these gains requires sound processes for selecting and delivering projects. This paper assesses the investment process from initial proposals through evaluation, discussion, selection, approval, implementation, and ex post evaluation. It finds that, although the policy process at each stage is clear, and the planning framework has central oversight, final choices of project are often sub-optimal. The paper identifies a need for stronger top-down influence in the planning process and more influence of economic-efficiency considerations in project selection. It also calls for efforts to broaden ex post assessment of transport investment projects and reduction in project delays.
\end{abstract}

Transport-infrastructure investment can substantially improve the environment for business and raise living standards. New or improved transport links alter the economic geography for businesses and households; reducing journey times, facilitating trade, connecting communities and widening access to jobs. Norway's oil wealth has meant substantial fiscal capacity to realise these returns. Spending on transport infrastructure as a share of GDP is indeed comparatively high, and has increased in recent years (Figure 1). Looking forward, fiscal room for such investment is likely to narrow under the adjusted fiscal rule (the move from a " $4 \%$ rule" to a " $3 \%$ rule", see the Assessment and Recommendations of the latest OECD Economic Survey of Norway, OECD 2018), making it all the more important that good investment choices are made. This paper focusses on the processes whereby new transport infrastructure projects are selected and delivered and suggests ways of strengthening the efficiency of investment. The analysis focuses on road infrastructure given that this accounts for most of investment (Figure 1).

1. Philip Hemmings is a Senior Economist at the OECD's Economics Department, email: philip.hemmings @oecd.org. Jagoda Egeland is an Economist at the OECD's International Transport Forum and Juan Garin is an OECD consultant. Thanks are due to Alvaro Pereira and Patrick Lenain (OECD Economics Department), plus colleagues from other Departments of OECD and experts from the Australian Government for their valuable comments and feedback. Special thanks are due to Damien Azzopardi for statistical assistance and to Brigitte Beyeler, Stephanie Henry and Dacil Kurzweg for administrative assistance. 
Figure 1 Norway makes sizeable investment in transport infrastructure

\section{A. General Government investment in transport}

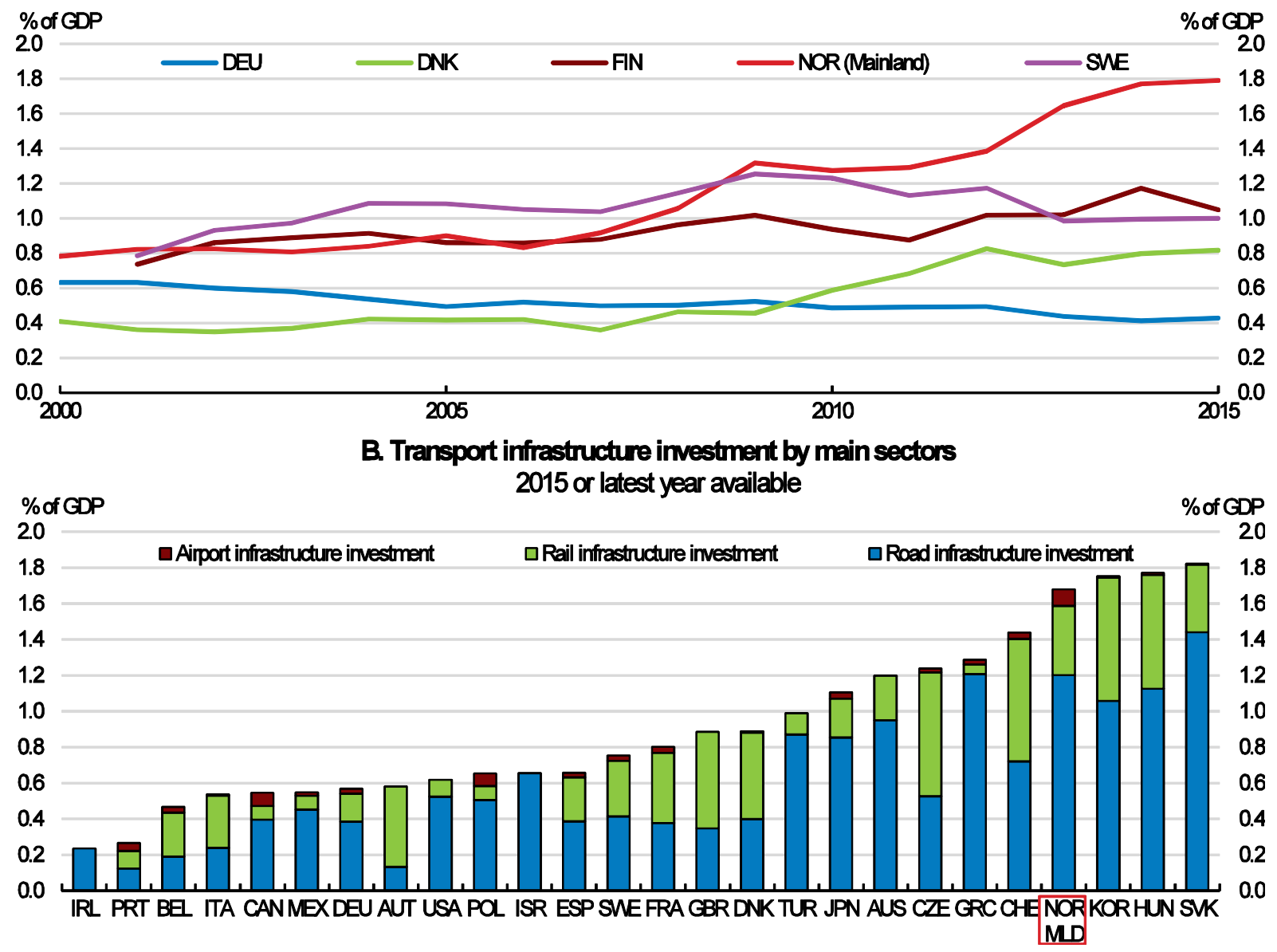

Source: OECD National Accounts and ITF databases.

\section{Geography and socio-political priorities strongly influence Norway's transport investment}

As in other countries, the nature and density of transport networks in Norway are partially shaped by population density. Norway has 17 persons per square kilometre, which is among the lowest population densities in the OECD area (Figure 2, Table 1) and similar to those of Finland and New Zealand. Low population density is loosely echoed in road density. Norway and Finland are particularly alike on this front, with around $25 \mathrm{~km}$ of road per square kilometre of land (and both countries consequently have a similar road-length per inhabitant, Table 1). Rail density, meanwhile, is substantially below that in Finland, and closer to that in Canada and Chile. Population density also influences other dimensions of transport networks; low-population-density countries involve longer linkages but these typically have lighter usage and fewer junctions and accommodations for other land uses and transport systems compared with highdensity countries. 
Figure 2 Low transport-network densities partly reflect low population density

2015 or latest year available, selected low-population-density countries

A Density of road

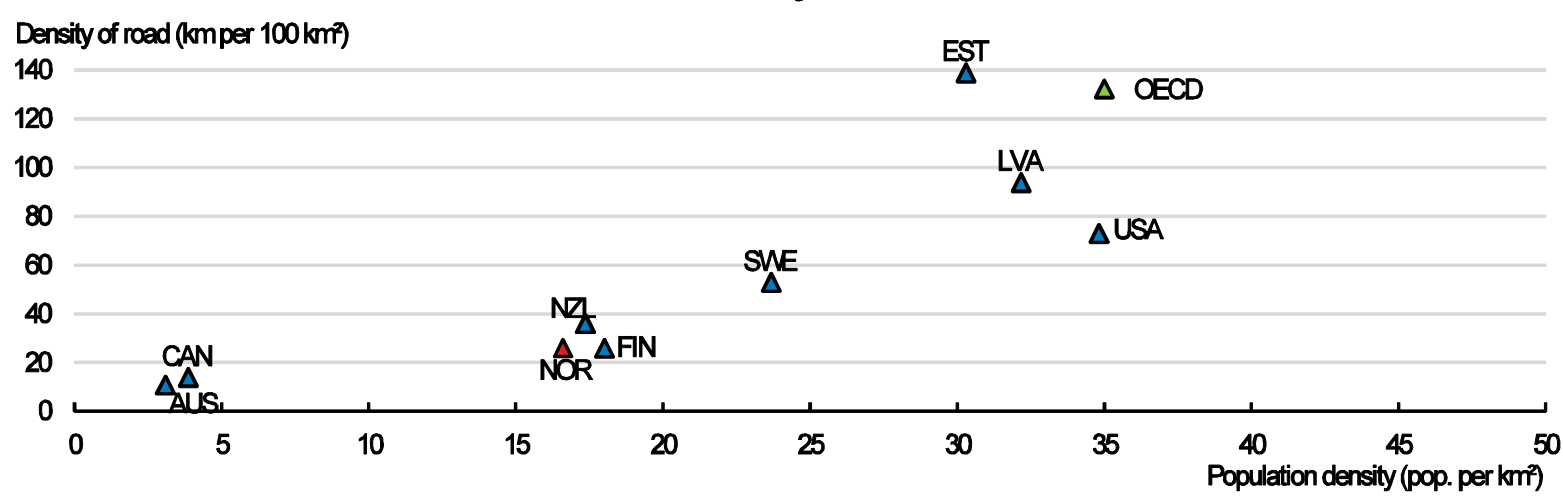

Density of rail lines (kmper $\left.100 \mathrm{~km}^{2}\right)$

B. Density of rail lines

5.0

$\triangle \mathrm{OECD}$

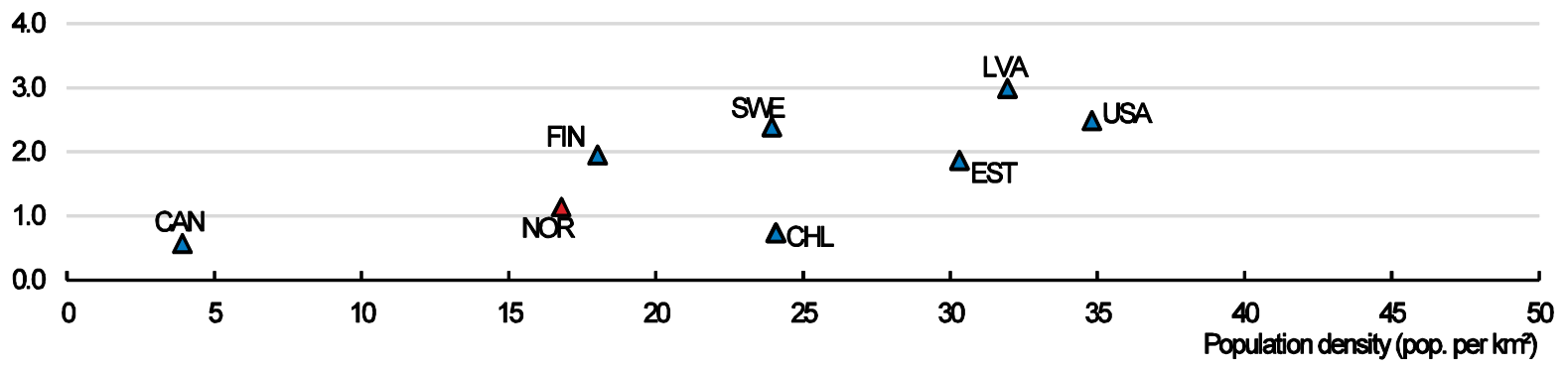

Source: OECD ITF database.

Table 1 Population and transport-network densities in selected countries

2016 or latest year available

\begin{tabular}{llllll}
\hline & $\begin{array}{l}\text { Population } \\
\text { density }\left(\mathbf{p e r} \mathbf{~ k m}^{2}\right)\end{array}$ & $\begin{array}{l}\text { Density of road } \\
\left(\mathbf{k m} \text { per } \mathbf{1 0 0} \mathbf{~ k m}^{\mathbf{2}}\right)\end{array}$ & $\begin{array}{l}\text { Road length per } \\
\text { capita }(\mathbf{k m} \text { per } \\
\mathbf{1 0 0 k} \text { inhabitants) }\end{array}$ & $\begin{array}{l}\text { Density of rail } \\
\text { track } \mathbf{( k m} \text { per } \\
\left.\mathbf{1 0 0} \mathbf{~ k m}^{2}\right)\end{array}$ & $\begin{array}{l}\text { Rail track per } \\
\text { capita }(\mathbf{k m} \text { per } \\
\mathbf{1 0 0 k} \text { inhabitants) }\end{array}$ \\
\hline Australia & 3.1 & 11 & 3560 & 0.11 & 38 \\
\hline Canada & 4.0 & 14 & 3618 & 0.57 & 146 \\
\hline Norway & 17.1 & 26 & 1566 & 1.14 & 68 \\
\hline New Zealand & 17.7 & 36 & 2075 &. &. \\
\hline Finland & 18.1 & 26 & 1444 & 1.95 & 108 \\
\hline Sweden & 24.2 & 53 & 2238 & 2.39 & 100 \\
\hline Estonia & 30.3 & 139 & 4587 & 1.87 & 62 \\
\hline Latvia & 31.7 & 94 & 2922 & 2.99 & 94 \\
\hline United States & 35.3 & 73 & 2097 & 2.49 & 72 \\
\hline Denmark & 133.0 & 176 & 1335 & 5.02 & 38 \\
\hline
\end{tabular}

Source: OECD ITF database.

Norway's elongated shape, mountainous topography and many steep-sided fjords also influence the density of transport networks, and, importantly this generates challenges in construction and maintenance, and affects costs. The Norwegian road network of 93000 kilometres $(\mathrm{km})$ contains approximately 1000 tunnels and 18200 bridges (Table 2). The Lærdal road tunnel is the world's longest, at $24.5 \mathrm{~km}$. In the rail 
network's $4000 \mathrm{~km}$ of track (mostly single line) there are nearly 800 tunnels and about 3000 bridges. In addition the long land border with Sweden involves cooperation on transport issues. Constructing new cross-country road and rail connections or improving existing linkages in Norway involves higher costs in some dimensions of engineering than in other countries, for instance terrain-related costs are often high. Meanwhile some dimensions of costs are likely to be lower. For instance in Norway costs relating to land purchase and compensation for new routes, and additional costs linked to putting transport routes through habited areas, are likely to be lower in Norway compared with those in high-population-density countries. However, certain efforts to compare project costs with other countries indicate cost differences narrow once such differences are taken into account. Norway's geography also means the country relies heavily on air and maritime transport. Indeed, Norway has 13 international airports, or roughly 3 per million inhabitants, which is by far the highest ratio in the OECD area (Figure 3).

Table 2 Norway's transport network: selected figures

\begin{tabular}{|lc|}
\hline Public roads, total km & 93000 \\
\hline of which National roads & 10500 \\
\hline \multicolumn{1}{|c}{ County roads } & 44000 \\
\hline Rounicipal roads & 38500 \\
\hline Road bridges (number of) & 1000 \\
\hline Rail network, km & 18200 \\
\hline Rail tunnels & \\
\hline Rail bridges & 4000 \\
\hline
\end{tabular}

\begin{tabular}{|c|c|}
\hline \multicolumn{2}{|l|}{ Airports } \\
\hline International & 13 \\
\hline State-owned & 46 \\
\hline
\end{tabular}

National ports

Source: Norwegian Public Roads Administration, Norway State Railway (NSB), SSB 
Figure 3 A comparatively large number of airports

International airports per million population, 2015 or latest year available

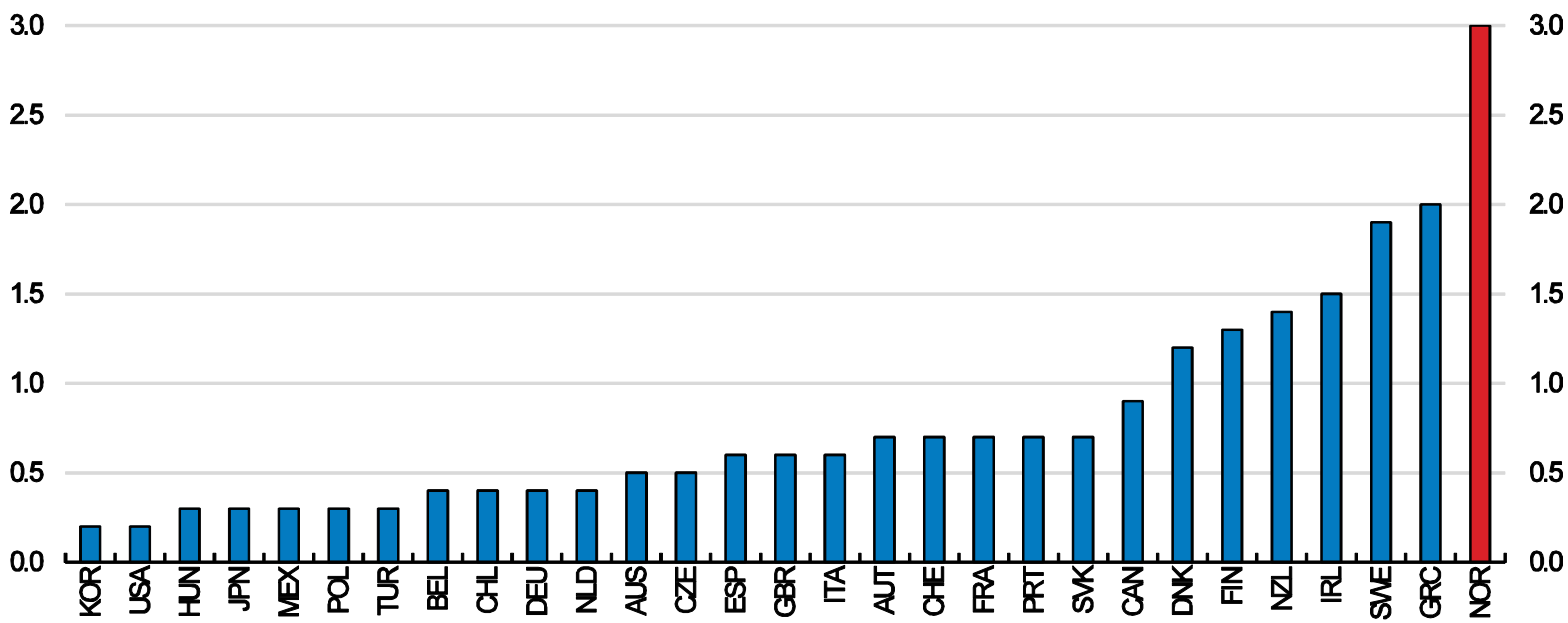

Source: OECD ITF database.

Norway's policy emphasis on sustaining rural and remote regions plays an important role in transport infrastructure development. There has long been substantial political support for sustaining communities in rural and remote areas, which often face challenges in economic viability and depopulation. The support for rural and remote areas features in a wide range of policies including subsidies for transport and telecommunication requirements as well as health and cultural facilities and in economic activities (notably agriculture support). These supports have been successful at maintaining a relatively high share of rural population (47\% of the population live in predominantly rural areas versus an OECD average of $25 \%$, OECD 2016). In addition, the support for rural and remote areas has important implications for the prioritisation of projects in transport infrastructure.

Despite comparatively high spending, Norway's transport network does not rank highly according to some indicators. In the World Economic Forum (WEF) indicator system Norway is middle-ranking among OECD countries for transport infrastructure overall (it ranks 32 out of 138 among all countries covered by the WEF) and scores poorly on the road-quality component (Figure 4). The WEF rankings reflect views expressed by samples of business managers and so are unlikely to represent a universal view on the quality of transport infrastructure. Nevertheless the scores suggest room to better match infrastructure development with demands and expectations, at least as far as the business community is concerned. 
Figure 4 Mediocre scores in the World Economic Forum transport indicators

\section{A. Quality of overall infrastructure'}

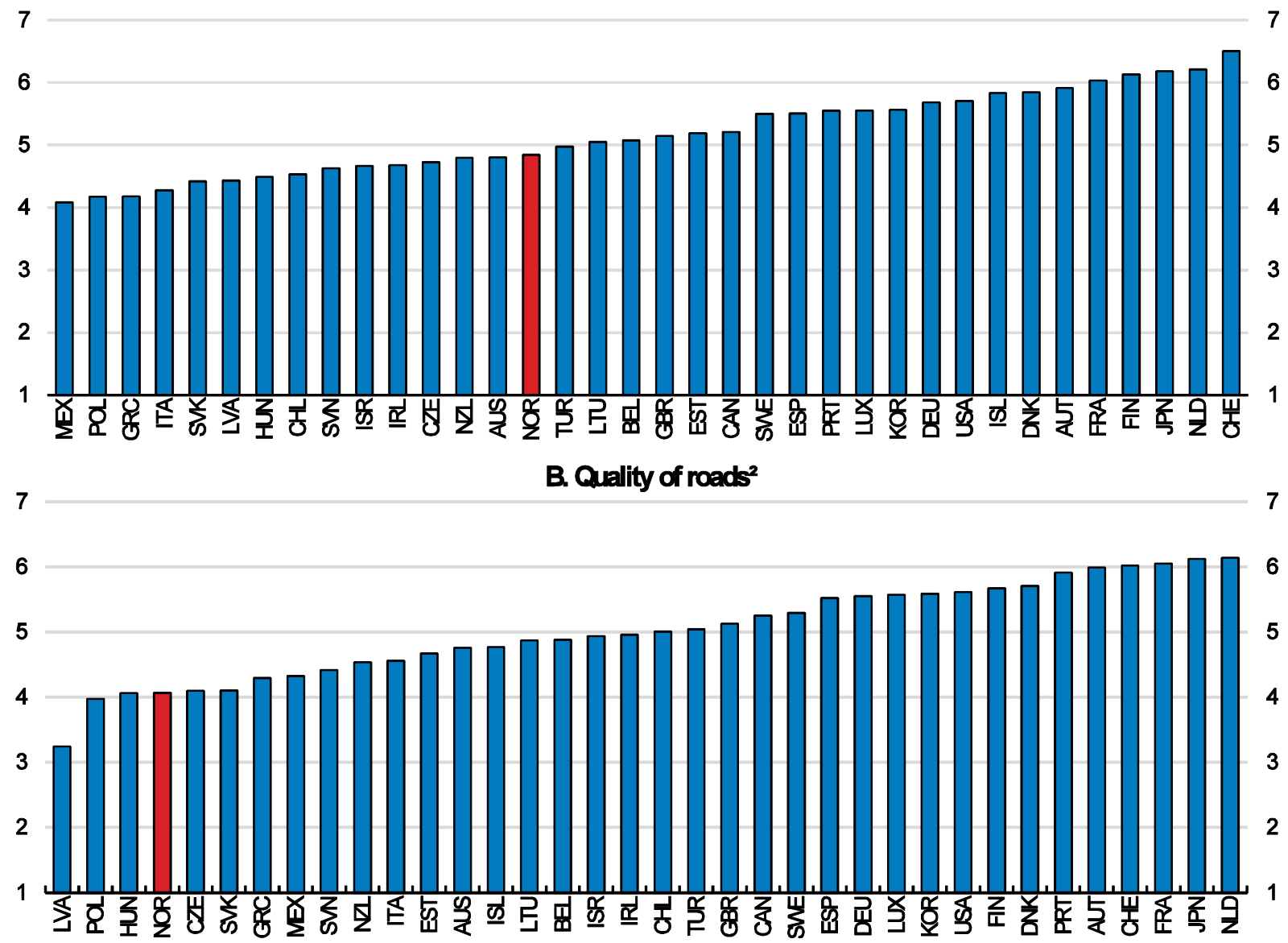

1. The score is based on the assessment of business leaders operating in the country in response to the question: how do you assess the general state of infrastructure (e.g. transport, communications and energy) in your country? [1 = extremely underdeveloped - among the worst in the world; $7=$ extensive and efficient - among the best in the world]. 2. In your country, how is the quality (extensiveness and condition) of road infrastructure [ $1=$ extremely poor-among the worst in the world; 7 = extremely good-among the best in the world].

Source: World Economic Forum Global Competitiveness Index dataset.

\section{Funding and responsibility for transport infrastructure}

In Norway, central government is responsible for building and maintaining the national road and rail networks as well as fairways and state-owned ports and airports. Meanwhile, counties are responsible for building and maintaining regional roads as well as local and regional transport; and, municipalities for roads and all other ports in their areas. Transfers from central government finance a significant share of regional and local transport infrastructure. Special arrangements for cities have been introduced recently, with central government providing earmarked financial support to cover half of large transportinfrastructure investments, such as the Oslo metro extension. County roads are covered by expenditure equalization schemes that are determined in part by factors such as road length and operating costs. In addition to central and non-central government financing, transport-systems receive funding from various sources. Notably, tolls systems have increased during the last years as a method of partial financing of new road projects; as of September 2017 there were approximately 60 toll systems operating. Some of the toll 
systems operate on a number of urban ring roads and on some projects where tunnels or bridges have been built as a replacement for ferries.

The government cabinet is the core decision maker for transport policy. In a formal sense, decisions about implementation are thus "top down". In practice, and as in most OECD countries, responsibilities (and influence) are highly dispersed. By the time projects come before the cabinet for approval, they have typically got there by a "bottom up" process. The Norwegian government model is characterised by core line ministries that develop new policy, and executive agencies that are responsible for executing policy (OECD, 2013). Transport infrastructure conforms to this model with the Ministry of Transport and Communications having overall responsibility for the sector, but with planning and implementation devolved to four executive agencies covering the different transport modes. There are three governmentadministered executive infrastructure agencies in the transport sector, the Norwegian Public Roads Administration (NPRA, Statens Vegvesen), the Norwegian Railway Directorate (Jernbanedirektoratet), and the Norwegian Coastal Administration (Kystverket). For air transport the agency role is performed by the government-owned company Avinor AS.

\section{Recent reforms have included establishment of new road and rail companies}

A restructuring of the transport sector was carried out in 2016 and early 2017. It focused on improving the delivery and implementation of projects and involved the creation of two new state-owned companies: a rail infrastructure company (Bane NOR SF) tasked with building and operating the rail network, and a New Roads Company (Nye Veier AS).

The rail-sector restructuring has separated out strategic and operational roles. The previous rail authority has been split into the Rail Directorate, responsible for developing policy and the long-term strategy for the sector, and a unit responsible for delivering and managing rail infrastructure (Bane NOR). Bane NOR is by far the larger in terms of staff numbers; it has inherited most of the employees from the previous organisation. The Rail Directorate's responsibilities include preparation of inputs into the National Transport Plan (NTP, see below). Furthermore, it handles the budget for the sector and strikes agreements with Bane NOR and the other actors in the rail sector. The agreements determine the priorities and timing of investment in new lines, and specify performance and service levels. The Rail Directorate has primary responsibility for concept-stage studies for new investment, but may order such studies from Bane NOR. In addition, Bane NOR engages with local authorities during the planning process, conducts stakeholder consultations, and secures land for projects.

Road-sector reform saw establishment of the New Roads Company (NRC) for delivering new motorways (Box 1). It has been allocated a portfolio of $530 \mathrm{~km}$ of motorways to build and operate over the next 20 years for a budget of NOK 148 billion. The NRC is principally funded from the state budget and tolls, but can also access a state funded credit facility (up to one year duration). While the NRC has no leeway on the selection of road projects it delivers, it does have discretion with regard to the timing and sequencing. The aim is that this operational flexibility will enable it to generate cost savings. Reportedly, the Company's first road project was estimated at NOK 4 billion but will be delivered for NOK 3 billion, providing encouraging initial evidence that this new approach can deliver substantial savings. The fact that governments have already used public-private partnerships (as an alternative to regular procurement) for some new road infrastructure (and intend to use more), is likely to incentivise efficiency in the NRC.

Such corporatisation can enhance efficiency if it introduces appropriate incentives and targets, and provides sufficient managerial and operational freedom to the infrastructure company. Given that the reforms came into effect only in 2016 and early January 2017, it remains to be seen whether these new structures will be effective at improving value for money in infrastructure delivery. 


\section{Box 1 The role of the Norwegian Public Roads Administration}

The Norwegian Public Roads Administration (NPRA) is responsible for planning, building, operating, and maintaining all national and county roads. It comprises five regional units plus the Directorate of Public Roads, whose responsibilities include strategic planning, international activities, and traffic safety (NPRA, 2016). Of the over $90000 \mathrm{~km}$ of roads, about $10000 \mathrm{~km}$ are national roads and about $44000 \mathrm{~km}$ are county roads. The NRPA is responsible to the Ministry of Transport and Communications for national roads and to county councils for matters related to the county roads. The remaining $39000 \mathrm{~km}$ are municipal roads, for which the NPRA is not responsible (NPRA, 2013).

\section{Transport-infrastructure investment is driven by multi-annual National Transport Plans}

An infrastructure investment programme should be underpinned by a long-term strategy that defines future needs and identifies solutions for meeting those needs as efficiently as possible. Large infrastructure investments involve different policy areas and sectors, resulting in complex decision-making processes involving multiple stakeholders and levels of government. The OECD's Framework for the Governance of Infrastructure underscores the principles of good practice (Box 2) and the OECD's International Transport Forum has identified best-practice principles in strategic planning (OECD/ITF 2017a).

\section{Box 2 OECD Framework for the Governance of Infrastructure}

1. Developing a strategic vision. Establish a national long-term strategic vision that addresses infrastructure service needs. The strategy should be politically sanctioned, coordinated across levels of government, take stakeholder views into account and be based on clear assumptions.

2. Managing threats to integrity. Corruption entry points should be mapped at each stage of the public infrastructure project, and integrity and anti-corruption mechanisms should be enhanced.

3. Choosing how to deliver infrastructure. When choosing how to deliver an infrastructure service, i.e. delivery modality, government should balance the political, sectoral, economic, and strategic aspects. Legitimacy, affordability and value for money should guide this balancing.

4. Ensuring good regulatory design. Good regulatory design and delivery are necessary to ensure sustainable and affordable infrastructure over the life of the asset.

5. Integrate a consultation process. The consultation process should be proportionate to the size of the project and take account of the overall public interest and the views of the relevant stakeholders. The process should be broad-based, inspire dialogue and draw on public access to information and users' needs.

6. Coordinate infrastructure policy across levels of government. There should be robust co-ordination mechanisms for infrastructure policy within and across levels of government. The co-ordination mechanisms should encourage a balance between a whole-of-government perspective and sectoral and regional views.

7. Guard affordability and value for money. Governments must ensure that infrastructure projects are affordable and the overall investment envelope is sustainable. The asset should represent value for money. This requires the use of dedicated processes, a capable organisation and relevant skills.

8. Generate, analyse and disclose useful data. Infrastructure policy should be based on data. Governments should put in place systems that ensure a systematic collection of relevant data and institutional responsibility for analysis, dissemination, and learning from this data.

9. Make sure the asset performs through its life. Ensure a focus on the performance of the asset throughout its lifespan by putting in place monitoring systems and institutions.

10. Public infrastructure needs to be resilient. Infrastructure systems should be resilient, adaptable to new circumstances and future proof. Critical risks materialise and technological change can fundamentally disrupt sectors and economies. 
Norway's system of rolling National Transport Plans (NTPs) is intended to address these challenges. The Plans are submitted by government to parliament in the form of a white paper. Until recently, the Plans were made every four years and spanned a 10-year planning period (in effect, each plan comprised four "core" years plus six "out" years). The latest Plan (Box 3) has a 12-year period (six core years plus six out years). Under the four-year cycle, preparation of the NTP usually began soon after a new government took office with the final selection of projects taking place in the run-up to the next general election. The change of timing under the latest Plan potentially has some significance for governance (discussed in later sections). The Plans are developed jointly by the three transport agencies, plus Avinor, and this is a core mechanism for ensuring a multi-modal approach to transport development. The joint development includes, for instance, co-operation in determining the key macroeconomic assumptions to be used for future transport projections and in the development of common methodologies. The Plans cover all transport infrastructure with substantial central-government funding, which in practice means almost all major projects. The Plans cover national roads (but not municipal or county roads), rail, and state-owned airports and ports. The Plans can also include urban transport infrastructure and increased capacity and reliability in central telecom infrastructure (see Box 3).

\section{Box 3 The new National Transport Plan}

The new NTP, covering 12 years 2018-2029, was submitted to parliament in April 2017 (NTP, 2017). The strategy for mobility between regions focuses on improving connectivity in the road and rail networks, while for urban areas the focus is on developing public transport, cyclist and pedestrian systems. In addition, the plan focuses on achieving zero-emissions growth. It envisages that by 2025 all new cars, city buses and light vans will be zeroemissions vehicles, and that walking, cycling and public-transport usage will have substantially increased. Centralgovernment funding for urban infrastructure will be conditional on "urban environment agreements" struck between the central government, county authorities and municipalities. Furthermore, the plan specifies that land-use plans for the larger urban areas must also be aligned with the zero-growth objective.

Plans for rail envisage continued development of InterCity routes with double track lines. The Stad Ship Tunnel maritime transport project, boring a ship-going tunnel through a peninsula, has been proposed in the plan, though it has been scheduled to start at the end of the first planning period.

The specific guidelines given by the Ministry of Transport to the three transport agencies, plus the state-owned airport company, Avinor, included calls for greater emphasis on "socioeconomic profitability", civil protection and further work on making standards consistent. As usual in the NTP process, the Ministry specified that certain projects must be included in the plan, in some cases because they are already initiated.

The proposed budget for the 12-year plan is NOK 1064 billion, including toll revenue. This is a substantial increase over the previous plan (NOK 664 billion in the 2014-2023 NTP), implying an average allocation of NOK 90 billion per year, or around $2.7 \%$ of current annual GDP. Road-transport spending accounts for $57 \%$ of the proposed budget, and rail transport 35\%.

Source: NTP (2017)

The submission, selection and delivery of infrastructure via the Plans essentially run as follows:

- The transport agencies (plus Avinor) propose projects for incorporation into the Plan according to guidelines delivered by the Ministry of Transport and Communication and after internal discussion and consultations with the relevant local and regional authorities, which themselves often have projects that they wish to promote.

- Large projects (defined as those with estimated costs exceeding NOK 750 million) that require central-government financing are put through the first of a two-stage "quality assessment" 
appraisal process (this first stage is referred to as "QA 1"). The process is overseen by the Ministry of Finance and incorporates quality assurance by independent reviewers.

- The Ministry of Transport and Communication prepares the National Transport Plan as a white paper. As part of the process of preparing this plan, a shortlist of priority projects is selected at the political level by the government of the day, with economic appraisal as part of the project information feeding into this choice. This is a critical step in the selection process. The formulation of the latest plan was unusual in that, rather than the government selecting projects following internal discussion, there was open political negotiation among the governing coalition via the Parliamentary Committee for Transport and Communications. As mentioned above, to date, finalisation of the white papers has taken place in the run up to general elections, but this may not be the case for the next plan.

- The National Transport Plan is then submitted as a white paper to parliament for discussion. Large projects are put through the second stage of the quality assurance process ("QA2"). Projects are rarely rejected at this point in the process as they have considerable (political) momentum, with typically several years of deliberation, transport appraisal as well as gathering both local and national support (see Welde and Odeck, 2017 for discussion).

- Projects enter the construction phase and a subset of projects is subject to ex post evaluation.

Infrastructure planning in metropolitan areas has an extra degree of complexity because it typically involves multiple municipalities, as well as county- and state-level government (the city of Oslo is an exception since it constitutes both a county and a municipality, Box 4). Negotiations between central and sub-national governments relating to metropolitan infrastructure development are based on the National Transport Plan. In the largest metropolitan areas long-term vertical collaboration has been facilitated in recent decades by co-financing agreements for transport infrastructure, called "packages" (Bypakker). Past efforts to strengthen co-ordination include, for instance, the adoption of a joint regional land-use and transport plan between Oslo and the county of Akershus in 2015. Urban growth agreements (formerly urban environment agreements) have been introduced to strengthen coordination, and to ensure that the growth in passenger traffic in the urban area shall be covered by public transport, cycling and walking

\section{Box 4 Infrastructure planning and financing in the city of Oslo}

The city of Oslo is the largest metropolitan area in Norway, and is both a municipality and a county. The Oslo authorities have a "climate budget" and the authorities' vision is for a car-free inner city, and for all growth in passenger traffic to be covered by walking, bicycling and public transport, instead of private car use.

The metropolitan transport authority (Ruter As) is responsible for planning, building and operating Oslo's public transport. It is $60 \%$ owned by Oslo County and $40 \%$ owned by neighbouring Akershus county. Public transport planning is performed jointly between the Rail Directorate, the Norwegian Public Roads Administration, and Ruter As. Long-term transport planning is currently guided by the "Concept Study Oslo Hub" of 2016, which is also designed to be consistent with land-use strategy for the city.

A regional transport model developed by the road and rail authorities identifies future transport needs, and the project planning methodology is the same as that used by the central government. Stakeholder consultations play an important role and take place at an early stage in the project lifecycle.

Public transport development and operation in Oslo is partly financed from the city's ring-road tolls (neighbouring municipalities also receive some of the toll revenue). Central government provides financing too, notably for national road projects, cycling lanes and public-transport projects. As mentioned in the main text, vertical collaboration is facilitated by "packages" (Bypakker)---long-term transport plans covering both public and private transport. In the case of Oslo, the Bypakke Oslopakke 3 is an important part of urban planning. This Bypakke is part of Oslo's Urban Environment Agreement, which endeavours to strengthen co-ordination of development of housing, land use and the transport system. 


\section{Project appraisal and selection processes}

Statutory appraisal and selection procedures are comprehensive. In line with best international practice, most transport projects in Norway undergo a thorough assessment of their positive and negative impacts, both directly on transport users but also on the wider economy and society (see for example $\mathrm{OECD} / \mathrm{ITF}, 2017 \mathrm{~b}$ ). The requirements in terms of analytical work are set out in the government's Instructions for Official Studies of Central Government Measures (DFØ, 2016) which apply to all public spending measures. The Instructions require that central government bodies conduct impact assessments during the development of measures, and economic analyses for measures that are expected to give rise to major benefits or costs. Most national transport projects fall into this category. As mentioned above, in addition there are "quality assurance processes" (QAs) for major transport projects (further discussion below).

As in most OECD countries, cost-benefit analysis (CBA) is used as to rank alternative projects and alternative versions of the same project. In Norway, the CBA guidelines are embodied in an impressively comprehensive document, "Circular R-109" (see Box 5). The guidelines include requirements to account for the wider ramifications of transport projects using supplementary estimates and analysis, including environmental impacts. Work on improving CBA continues. For instance, a common methodology for assessing the wider economic benefits (and costs) is currently being developed by the transport agencies.

Substantial consultation goes into submissions to the NTP white paper. Project proposals emerge from a process involving inputs from ministries and a wide range of bodies and stakeholders. These are evaluated via "Concept Evaluations" by the three transport agencies plus Avinor, following guidelines provided by the Ministry of Transport and Communications. The evaluations include assessment of the needs addressed, specification of project requirements, identification of alternative solutions and consultation with stakeholders (county and municipal authorities, businesses and industry organisations). In addition, the evaluations issue guidance for the pre-project phase and include cost-benefit analysis.

\section{Box 5 Norway's “Circular R-109” guidelines for cost-benefit analysis}

Cost-benefit analysis depends critically on underlying assumptions and forecasts of both costs and benefits. For transport investment, past experience usually provides sufficiently accurate estimates of engineering costs and land acquisition, as well as maintenance costs in future years. However, the measurement of benefits is typically more challenging. Some benefits can be ascribed a monetary value, typically time and lives saved, but there is a wide range of methods, and therefore outcomes. Similar issues apply to the choice of discount rate. Thus, having the same benefit-calculation and discount-rate methodologies are applied across CBA calculations is critical.

In Norway, cost-benefit analysis for appraising public investment projects is governed by "Circular R-109", which is a set of recommendations on CBA presented to the Ministry of Finance by a government-commissioned committee in 2012. It provides an impressive account of the theory and evidence on cost and benefit measurement and raises key issues on a wide range of issues, including:

- Timespan of cost and benefit calculation: the committee recommended 40 years (instead of 25 years), which is the same period used in EU project appraisal.

- Work time valuation: the Committee noted that although in theory, shorter travel times could lead to longer working hours, and higher production and incomes, in practice, working hours are not usually flexible and assessment is complicated by the fact that employees often do some work while travelling.

- Leisure time valuation: the Committee noted that, in theory, the real net wage measures the value of leisure at the margin, but in practice, because of inflexible working hours, fixed annual salaries, and other considerations, the value of leisure could be higher or lower than this. 
- GDP growth and valuing time: the report underscores that GDP growth implies growth in the value of time in work or leisure and that this needs to be reflected in CBA.

- Environmental goods valuation: The Committee concluded that information on willingness to pay for environmental goods was too weak to be of use but that health and mortality impacts of environmental goods could be taken into account.

- Social discount rate: the Committee recommended that for projects in direct competition with those in the private sector, the discount rate faced by private enterprises should be used; otherwise a real risk-adjusted rate starting at $4 \%$ for impacts in the first 30 years with declining values in later years.

- Measurement of wider impacts: the Committee found room to widen the impacts covered in CBA. For instance, it recommended supplementary assessment of interaction between transport project and urban productivity, and the reporting of wider impacts on labour supply, incomes and land values.

- Road tolls: the Committee recommended that public-road tolls should not be imposed if there is no evidence of queuing or if the cost of collecting tolls exceeds their revenue.

Source: Norwegian Public Roads Administration.

\section{The two-stage quality assurance process for large projects}

Projects with estimated costs in excess of NOK 750 million are subject to additional scrutiny via a two-stage quality assurance process (see Samset and Volden, 2013) (Figure 5). The process includes input from independent reviews; reflecting Norway's comparatively wide use of external review in assessing government-led project compared with many other countries. The quality assurance process was initially implemented to combat cost overruns (Odeck et al., 2015):

- QA1 focuses on quality assurance of choice of concept. It is conducted prior to the government cabinet's selection of projects for inclusion in the National Transport Plan;

- QA2 focuses on quality assurance of the management base and cost. It applies to projects that are included in the National Transport Plan but have yet to be submitted to parliament for approval and funding.

The central purpose of QA1 is to check, at a relatively early stage, that the project has undergone a process of "fair and rational" choice. It is conducted by the responsible ministry or government agency and includes investigation of alternative solutions, socio-economic impacts and relevance of the project to transport needs. There is emphasis on environmental and social impacts, land-use implications and regional development. This evaluation, inter alia, must include a "do-nothing" option ("zero option") and at least two alternative and conceptually different options. The external reviewers' role includes analysis as well as review of documents. For instance the external reviewer is required to undertake a cost-benefit analysis of impacts that incorporates risks (Figure 5).

The purpose of QA2 is to check the quality of the inputs to decisions, including the cost estimates and uncertainties associated with the project, before it is submitted to parliament to decide on funding allocation. It includes assessment of cost estimates derived from basic engineering work and assessment of at least two alternative contracting strategies. Notably, however, QA2 does not include revisiting and updating the cost-benefit analysis performed in QA1, unless the project seems to have been significantly altered from the option chosen at QA1. In addition, QA2 focuses on project management in the implementation phase. According to Odeck et al. (2015), there is evidence that QA2 has successfully reduced cost overruns but it also appears to have prompted cost overestimation. 
Figure 5 Norway's Quality Assurance regime for major public investment projects

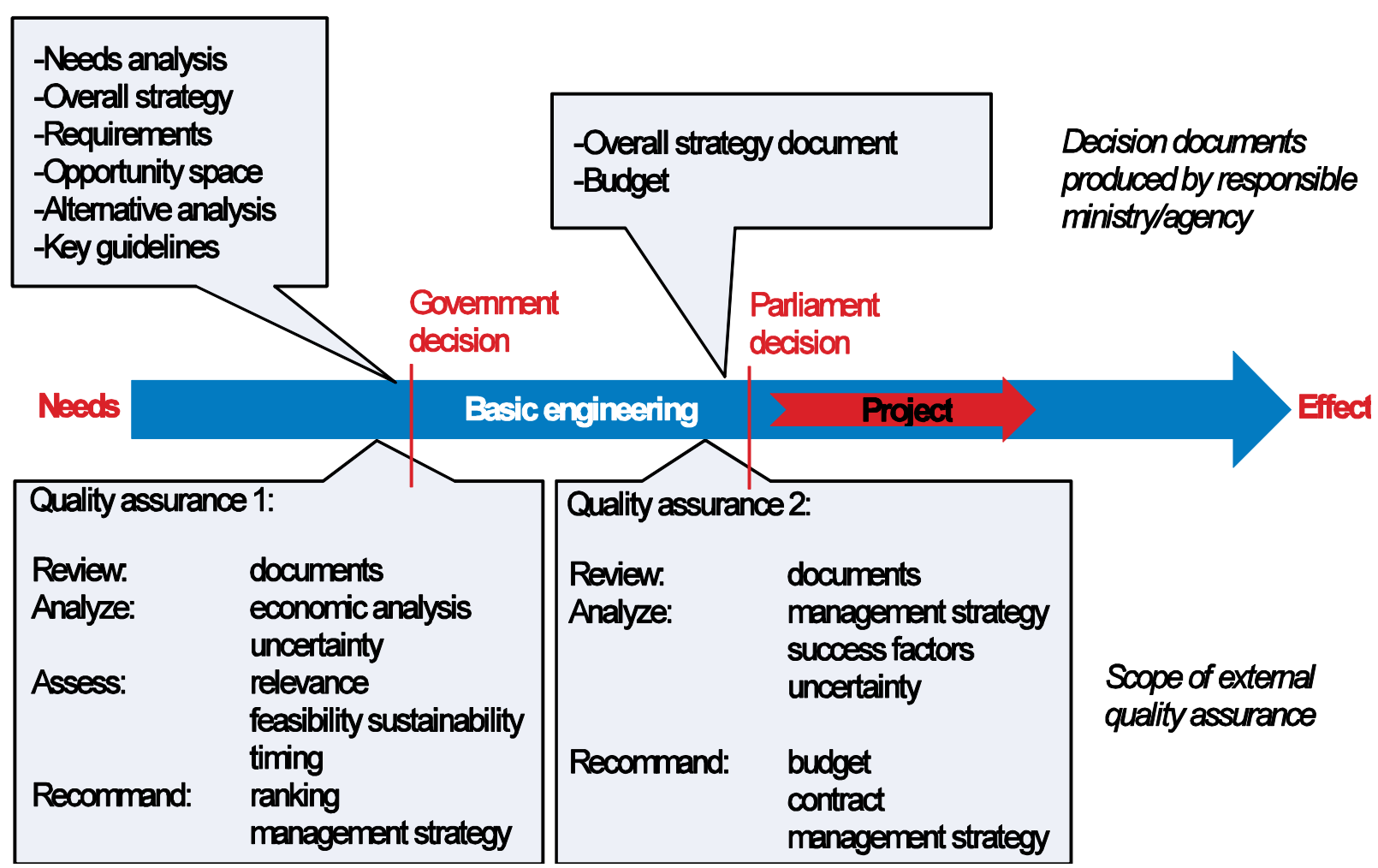

Source: Norwegian University of Science and Technology (http://www.ntnu.edu/concept/qa-scheme)

\section{Challenges in the project appraisal and selection processes}

\section{Economic efficiency considerations do not have enough influence}

The process described above has admirable features. There is considerable early-stage consultation and discussion between the agencies and lower levels of government, as well as with other interested parties. This facilitates stakeholders' ability to influence projects as modifications are easier and less costly to make. The requirements for CBA in the project appraisal and selection process and other objective analyses are comprehensive.

Despite these sound features, economic efficiency considerations often have only weak influence in actual project selection. Instead, selection is typically dominated by practices that reflect interested parties pushing projects for approval that are of particular benefit to them. This surfaces in:

- Lowballing of early-stage cost estimates (cost estimates that are made prior to official CBA analysis). Some reports claim that presentations of projects in the initial stages of the process often use cost estimates that are widely known to be inaccurate (Andersen et al, 2016).

- Projects selected with poor CBA scores. Often, projects are selected onto National Transport Plans despite their poor CBA ratings. The political negotiations that make the selection of project for the Plans have a reputation for attaching little importance to the CBA analysis. This has been confirmed in research. Sager (2016), for instance, illustrates that costs exceed benefits for most of the major road projects reports initiated in the period 2014-17 (Table 3). Analysis by Eliasson et al. (2015) of projects selected for the National Transport Plan 2014-23 confirm there is little 
consideration of project efficiency (Figure 6). For example, the net benefits of the projects in the portfolio hardly differs from that expected under random selection, despite there being no shortage of projects with good CBA outcomes among the candidates for selection.

- Cost growth in latter stages of the selection process, specifically between the two stages of the quality assurance process (QA1 and QA2). Indeed, project costs sometimes rise substantially above those calculated in the CBAs (Welde and Odeck, 2017). The cost increases typically involve specification upgrades ("gold plating") or project modifications, for instance arising from discussions with local government. Furthermore, late-stage cost inflation is likely to be more prevalent where costs have been lowballed earlier on. Cost increases mean cost-benefit calculations conducted at later stages of the process typically show lower net benefit compared with earlier calculations.

In sum, the outcome of Norway's project selection process, too often, results in elegant but costly solutions to seemingly minor problems from an economy-wide perspective, such as tunnels under fjords in sparsely populated regions. The underlying politics of these choices often reflects, as noted above, Norway's longstanding policy emphasis on sustaining communities and industries in rural and sparsely populated regions.

Table 3 Benefit-cost summary for major road corridor projects initiated in the period 2014-2017 (NOK million)

\begin{tabular}{|c|c|c|c|c|}
\hline Corridor & $\begin{array}{l}\text { Number of } \\
\text { projects }\end{array}$ & Net benefit & Cost & $\begin{array}{l}\text { Net Benefit to } \\
\text { Cost ratio }\end{array}$ \\
\hline 1. Oslo-Svinesund-Kornsjø & 1 & -860 & 1830 & -0.47 \\
\hline 2. Oslo-Ørje/Magnor & 2 & -1790 & 4750 & -0.38 \\
\hline 3. Oslo-Grenland-Kristiansand-Stavanger & 7 & 12080 & 33890 & +0.36 \\
\hline 4. Stavanger-Bergen-Ålesund-Trondheim & 4 & 18020 & 26800 & +0.67 \\
\hline 5. Oslo-Bergen/Haugesund. Branch via Sogn to Florø & 4 & -2320 & 8950 & -0.26 \\
\hline $\begin{array}{l}\text { 6. Oslo-Trondheim. Branches to Måløy, Ålesund, and } \\
\text { Kristiansund }\end{array}$ & 3 & 5210 & 6500 & +0.80 \\
\hline 7. Trondheim-Bodø. Branches to the Swedish border & 2 & -1740 & 5670 & -0.31 \\
\hline $\begin{array}{l}\text { 8. Bodø-Narvik-Troms } \varnothing \text {-Kirkenes. Branches to Lofoten } \\
\text { and the national border }\end{array}$ & 2 & -530 & 1890 & -0.28 \\
\hline
\end{tabular}

Source: Sager (2016) 
Figure 6 Investment efficiency of projects selected in Norway's National Transport Plan 2014-23

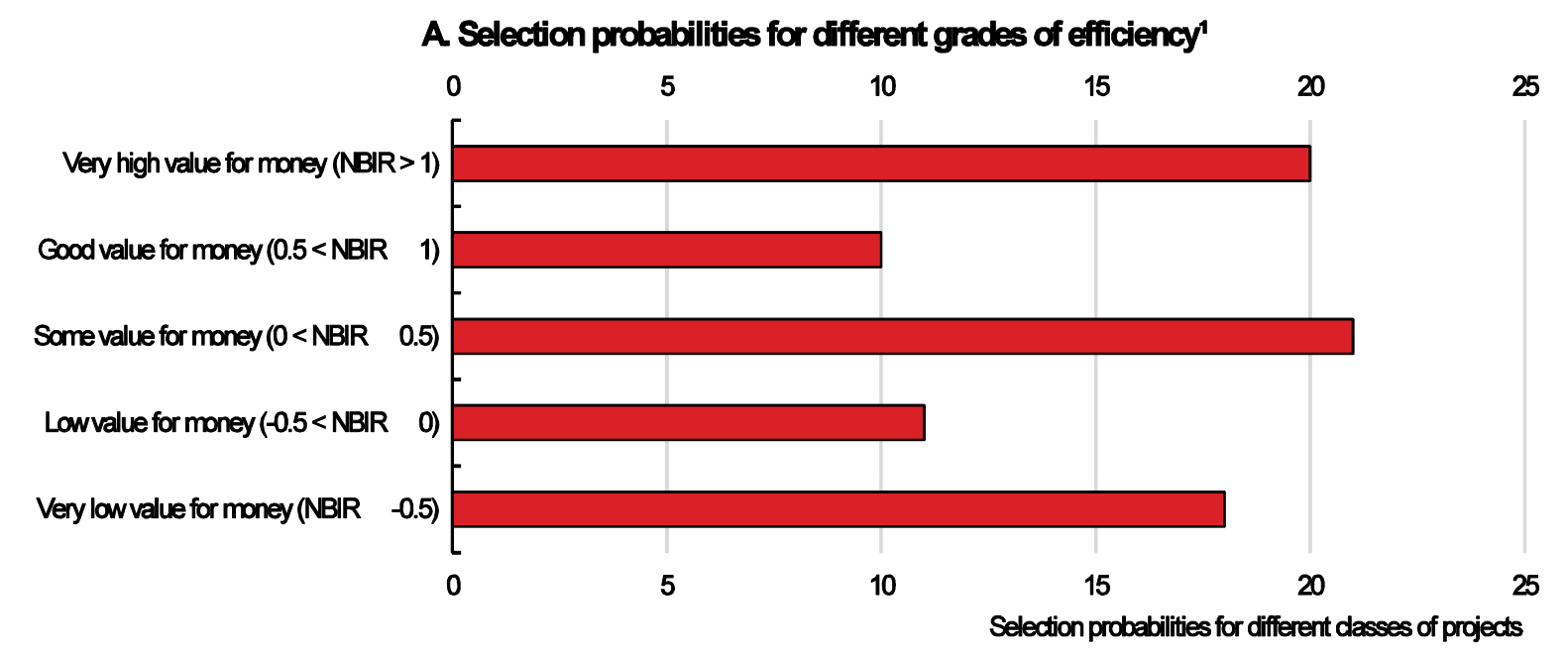

$\%$ of GDP

B. Benchmarking actual selection²

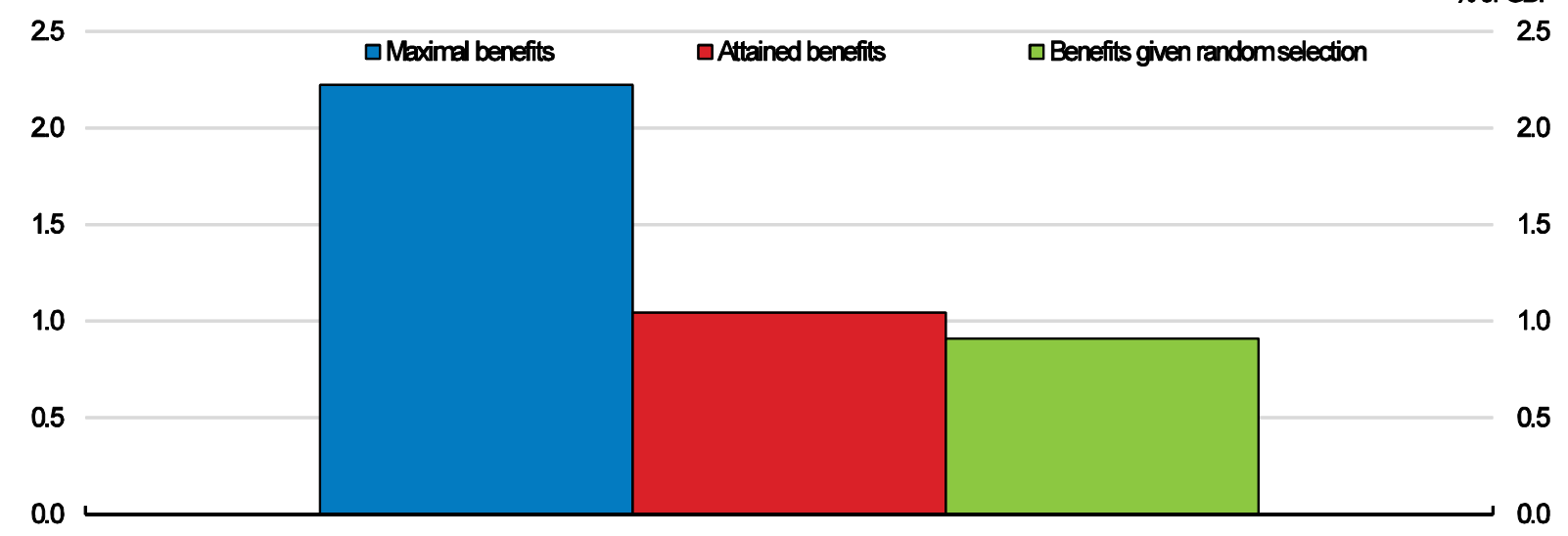

1. Panel A: NBIR, Net-benefit to Investment Cost Ratio. The probabilities show the proportion of projects selected by government in each of the classes of NBIR. For instance, the government chose $20 \%$ of the candidate projects that had NBIRs greater than one.

2. Panel B: "Attained benefit" is the total net benefit of the projects selected by the government. "Maximum benefit" is the maximum net benefit possible from the candidate projects for the same spending as in the attained budget. "Benefit under random selection" is the statistically expected benefit under random selection. The data are expressed as a \% of nominal annual GDP in 2012, the year in which the selection was made. The results shown here are those for the government selected projects in Eliasson et al (2015).

Source: Eliasson et al. (2015).

\section{Land-use planning often adds complications and delays}

Discontinuity between national-level infrastructure planning and local-level land-use planning often leads to implementation delays. In Norway municipal governments have considerable steerage on land-use strategy and planning (country-level government has some legal powers to impose plans on municipalities but in practice these are not much used). Municipal-government land-use plans are legally binding documents that detail permitted buildings, installations and activities. In addition, land-use legislation explicitly promotes preservation of farming activities and family farms. Transport infrastructure (including the national-level projects in the NTPs) must be integrated into the land-use plans before any construction work can begin. This gives municipalities significant influence on which projects can proceed and at what pace. Indeed, local-government control via land-use is often the cause of implementation delays and a source of project modification. To avoid these issues central government has begun to use planning 
provisions that allow it to develop combined land-use and transport plans for national-infrastructure projects ("state-determined" plans). The state-determined plans in effect mean central government dictate elements of regional or local land-use planning (for instance, so as to create a new transport route). According to the central government, local governments affected by state-determined plans have generally responded positively, and planning time has been reduced.

State-determined plans cannot be imposed in all contexts and conflicts between local plans and national policy will remain an issue. The conflicts not only often take a lot of time to resolve but also absorb administrative and policy-making resources as they involve negotiations between municipalities, counties and central ministries (if the parties fail to agree then the Ministry of Local Government and Modernisation intervenes). According to data provided by the Ministry of Local Government and Modernisation, in 2014 objections were expressed against 20\% of local land-use plans, with the majority resolved through negotiations and only a small minority required Ministerial intervention.

\section{Measures already taken include steps for more evidence-based project selection}

There is welcome concern in policy-making circles regarding the challenges in transportinfrastructure planning and selection outlined above. Indeed, there have already been positive developments. The latest National Transport Plan's shift to a 12-year plan period (instead of 10 years, see discussion above) is significant in that the plan for a six-year gap could imply that the next transport plan will be drawn up half way through a government's term of office (Norway has a fixed 4-year electoral cycle at national level). This would break with the tradition of transport plans being finalised in the run up to general elections, which many believe has contributed to an undesirable degree of politicisation in transport-infrastructure investment. However, the rolling of the next plan is not yet decided and it is possible that traditional timing will prevail.

In addition, efforts are underway to make project selection more strongly evidence-based. The new Instructions for Official Studies of Central Government Measures and the QA scheme reflect greater emphasis on evidence-based decision-making and value for money, as does the greater prominence given the cost-benefit analysis in the latest transport plan (Box 3). Measures include requirements to log changes in the scope and cost of projects, with large changes requiring discussion by government. While these steps almost certainly will have some positive impact on infrastructure decisions, they are unlikely to resolve the problems entirely. Therefore, this strengthening of procedures should be accompanied by other steps that raise awareness and concern for economic efficiency, and the desirability of speedy implementation, by policymakers at all levels of government (Sager, 2016).

\section{Further steps should include stronger top-down influence in the planning process}

Norway's transport-infrastructure selection, especially in the road sector, has strong "bottom- up" processes involving the regional offices of the NPRA with input from local governments. This is not unusual. Bottom-up processes feature strongly in infrastructure selection in most OECD economies, meanwhile strong top-down steerage tends to be less common as discussed in the OECD International Transport Forum's analysis of best practice in strategic planning (OECD/ITF, 2017a). There are, however, important merits to strong top-down steerage. It can bring good interdependencies both within and across sectors (e.g. transport and energy) and better incorporate emerging technologies into infrastructure planning needs (e.g. autonomous vehicles). Stronger top-down steerage in Norway may be particularly beneficial as it could act as a counterweight to the substantial bottom-up influence arising from groups in favour of supporting communities in rural and remote areas.

A range of technical changes to processes should also be considered to strengthen the role of economic analysis in project selection. "Soft" measures, for instance could include requiring a written 
explanation by government for the projects selected in the National Transport Plan. Hard measures could, for instance, comprise a new end-stage filter that requires a minimum net-benefit to cost ratio for projects to proceed further. In Denmark initial investment cost estimates are increased to allow for cost inflation in the planning phase ("buffers"). This may be a route for policy in Norway but this depends on whether this type of mechanism can transposed to the Norwegian planning process. At the same time, improvements to CBA should continue so as to strengthen its credibility. In addition, some claim (for instance Odeck et al., 2015) that obligations in financing infrastructure are not sufficient to incentivise socially beneficial or costeffective choices. Especially in road infrastructure, stakeholder participation in financing, notably as regards local and regional government is already fairly comprehensive. Nevertheless there may be room for alterations to central government financing of projects that ensure local and regional governments (and, by consequence their electorates) are more strongly guided by the prospect of participation in financing.

\section{Project implementation, delivery and ex-post assessment}

In Norway, the decision on delivery mode is separated from project selection under the NTP process. To date, most transport infrastructure delivery has used "traditional" public procurement processes whereby the agencies tender out approved projects to construction companies. Reforms in the 1990s more strongly separated procurement and state-run construction. In 2003 a state-owned construction company was established that has to compete on an equal basis with private companies. Today this company primarily focuses on operation and maintenance contracts, and not on construction projects. In general, Norway's procurement process is now regarded as efficient, with comparatively small cost and time overruns --- though this may also reflect that costs are often pushed up at earlier stages in the investment process.

\section{Greater use of public-private partnerships is planned}

There are plans to make greater use of public-private partnerships in the transport sector as an alternative to traditional procurement. Notably the latest NTP proposes using PPPs for three of the planned new motorway sections. In 2015 the government established a new framework for public-private partnership (PPP). The framework is developed primarily for the road sector but is of a general nature and therefore applicable to other sectors. Projects considered for PPPs tend to be large, and therefore attract debate. As is often the case in other countries, involving the private sector in what has traditionally been a government activity does not always command universal political support.

A key strength of Norway's approach is that PPPs receive neutral treatment from a public-sector budgeting perspective. The PPPs have the "build-operate-transfer" structure that is widely used elsewhere. However, budgetary allocations and appropriations for PPPs follow the same basis as projects executed through traditional procurement methods; they are not based on the disbursement of payments to the sponsor company. This results in the fiscal cost of PPPs being front-loaded in the budgeting system, differing little from other procurement methods from this perspective. This approach ensures that projects are selected on their merits (whether economic or political), rather than on their financing and delivery modality. Nevertheless, the criteria applied for selecting PPPs as a delivery modality could benefit from being more formalised and better communicated.

\section{Ex-post evaluations could play a more public role}

Requirements for ex post evaluations are set by the Ministry of Transport and Communication, and are conducted by the relevant agency. For instance, the road-transport agency, NPRA, conducts three to five evaluations each year, and the criteria for evaluation include that the project has been operational for at least 5 years and has a cost in excess of NOK 200 million (Nicolaisen and Driscoll, 2016). The 
assessments focus on testing the accuracy of the ex-ante CBAs and, as such, cover what the CBA analysis is able to capture.

Ex post evaluation by the government agencies could play a more significant role in providing insights into the performance and outcomes of transport infrastructure planning and decision making, and in informing the public. The evaluations could be broadened, notably with ex post assessment of wider social and environmental impacts, impacts from land-use change, or impacts on regional development. Broadening the evaluation framework would strengthen scope, accuracy and credibility. There are already blueprints on how to do this, for instance the Concept Research Programme at the Norwegian University of Science and Technology (Mennier and Welde, 2017 for a discussion).

Additional ex post evaluation that is more arms-length from policy should be considered. In selfevaluation there is a risk that some dimensions of project performance are not probed deeply. This could be addressed by complementing the existing internal and university-based evaluation with evaluation by an independent authority (perhaps along the lines of the European Court of Auditors). This could help strengthen the scope and visibility of ex post evaluation, expanding it beyond project-by-project CBAs to address broader questions regarding outcomes, performance, value-for-money, processes and portfolios of projects.

\section{Public awareness of economic efficiency could be strengthened}

Elected politicians are most likely to respond to demands from their constituents. Public awareness of, and demand for, efficient public investment is therefore an important influence on project selection. Norway's communication with the public on transport infrastructure is admirably transparent and encourages public participation. However, there may be ways of strengthening public awareness of valuefor-money issues that would feed positively through to decision making at the political level. Engaging civil society and the media are key channels for strengthening generating public awareness. An initiative by the Government Agency for Financial Management to provide courses on cost-benefit analysis for journalists exemplifies the type of measure that can be taken. 
ECO/WKP(2018)5

Summing up the strengths and weaknesses

Table 4 Strengths and weaknesses in transport infrastructure investment

\begin{tabular}{ll}
\hline \multicolumn{1}{c}{ Strengths } & \multicolumn{1}{c}{ Weaknesses } \\
\hline \multicolumn{1}{c}{ Planning and coordination } \\
\hline $\begin{array}{l}\text { Infrastructure planning and project development has effective } \\
\text { consultation and coordination with sub-national governments and }\end{array}$ & $\begin{array}{l}\text { The multi-level planning process can be slow and ponderous, and } \\
\text { provide opportunities for introducing changes that negatively affect } \\
\text { projects' scope and cost }\end{array}$ \\
$\begin{array}{ll}\text { The development of the National Transport Plan involves effective } \\
\text { cooperation across transport agencies }\end{array}$ & $\begin{array}{l}\text { Discontinuity between infrastructure planning (mostly national level) } \\
\text { and municipal-level land-use planning often delays implementation }\end{array}$ \\
\hline
\end{tabular}

\section{Project appraisal}

Norway has well-structured project appraisal and quality assurance processes, grounded in economic analysis

There is a clear and well-documented process and set of requirements for project preparation

Cost-benefit analyses are rigorous and based on comprehensive guidelines
Despite the rigorous CBA methodology and other quality assurance mechanisms, projects with weak scores in economic efficiency are frequently presented to politicians

Costs are often lowballed in initial stages and later significantly escalated, particularly between the two stages of the quality assurance process that applies to large projects

While ex post evaluations are regularly conducted for infrastructure projects their visibility and impact could be greater

\section{Project selection and prioritisation}

Political decision making on project selection is explicit and transparent
Multiple motives lie behind the final-stage political decision making and economic efficiency often does not have significant influence.

\section{Project delivery}

Public procurement process is generally regarded as efficient; cost and time overruns on finalised projects are generally small. The establishment of new road and rail management companies will further strengthen the system

PPPs focus on long-term efficiency and not on making short-run fiscal savings
The small cost and time overruns at the delivery stage partly reflect gold plating and other forms of cost inflation at earlier stages

The framework for the administration and oversight of PPPs is insufficiently formalised 


\section{Policy recommendations}

\section{Box 6 Recommendations on how to improve transport-infrastructure investment in Norway}

\section{Roles and responsibilities: strengthen top-down influence in the planning process}

- In metropolitan areas strengthen co-ordination across municipalities and counties

Project appraisal and selection: strengthen the influence of economic-efficiency considerations in project selection

- Consider hard rules that raise economic efficiency of selected projects, for instance via:

- A new end-stage filter that requires a minimum net-benefit to cost ratio for projects to proceed further

- Strengthen the role of economic analysis through "soft" measures:

- Require a written explanation by government for the selection of projects in the National Transport Plan, especially those with weak CBA results

- More strongly flag CBA results at the stage of political negotiation

- Monitor the impact of the recent introduction of the cost-target system that aims to limit cost inflation in the planning phase

- Repeat more often cost-benefit analysis at the second stage of the Quality Assurance process

- Continue refining CBA techniques and coverage with a view to strengthening accuracy, credibility and scope, especially as regards economic benefits that are difficult to monetise

- Re-examine infrastructure financing arrangements with a view to ensuring stakeholders with influence, such as local authorities and communities, also face an appropriate funding responsibility

- Devote more resources to drawing from transport-planning experiences in other countries

Implementation, delivery and ex post assessment: reduce delays, broaden ex post assessment

- Make greater use of "state-determined" planning in which central-government formulates integrated land use and transport plans for major national projects

- Widen the scope of the ex post evaluations conducted by the government transport agencies

- Strengthen independent ex post evaluations that complement the self-evaluations conducted by the transport agencies, for instance by establishing an independent evaluation body, or by tasking an existing body 


\section{REFERENCES}

Andersen, B., K. Samset, and M. Welde, (2016), "Low estimates - high stakes: Underestimation of costs at the front-end of projects", International Journal of Managing Projects in Business, 9(1), 2016.

DFØ (2016), Guidance notes on the Instructions for Official Studies - Instructions for Official Studies of Central Government Measures, Norwegian Government Agency for Financial Management (DFØ), Oslo, March 2016.

Eliasson, P., M. Böjesson, J. Odeck, and M. Welde (2015), "Does Benefit-Cost Efficiency Influence Transport Investment Decisions?", Journal of Transport Economics and Policy, Vol. 49, Part 3, July 2015.

Meunier D. and M. Welde (2017) "Ex-post evaluations in Norway and France", Transport Research Procedia, Volume 26, 2017.

Nicolaisen, M.S. and P.A. Driscoll (2016), "An International Review of Ex-Post Project Evaluation Schemes in the Transport Sector", Journal of Environmental Assessment Policy and Management, Vol. 18, No. 1, March 2016.

NTP (2017), National Transport Plan 2018-2029, Meld. St. 33 (2016-2017), Report to the Storting (white paper).

NPRA (2013), Key Figures. Norwegian Public Roads Administration.

NPRA (2016), About the Norwegian Public Roads Administration, Norwegian Public Roads Administration.

Odeck J., M. Welde, G.H. Volden (2015), "The Impact of External Quality Assurance of Costs Estimates on Cost Overruns: Empirical Evidence from the Norwegian Road Sector", European Journal of Transport and Infrastructure Research, 15(3), 2015.

OECD (2013), Value for Money in Government: Norway, OECD Publishing, Paris.

OECD (2016), OECD Economic Surveys: Norway, 2016, OECD Publishing, Paris.

OECD (2017), Getting Infrastructure Right: A framework for better governance, OECD Publishing, Paris.

OECD/ITF (2017a), Strategic Infrastructure Planning: International Best Practice, OECD Publishing, Paris.

OECD/ITF (2017b), Quantifying the Socio-economic Benefits of Transport, OECD Publishing, Paris.

OECD (2018), OECD Economic Surveys: Norway, 2018, OECD Publishing, Paris.

Sager, T.O., (2016), "Why don't cost benefits results count for more? The case of Norwegian road investment priorities", Urban, Planning and Transport Research, Vol. 4, No. 1, Taylor \& Francis Group. 
Samset, K., and G.H. Volden, (2013), Investing for impact. Lessons with the Norwegian state project model and the first investment projects that have been subjected to external quality assurance, Concept Report No. 36, Norwegian University of Science and Technology.

Welde M. and J. Odeck (2017): "Cost escalations, in the front-end of projects - empirical evidence from Norwegian road projects", Transport Reviews, Volume 37, 2017. 